\title{
Metabolizable energy for piglets in the nursery phase submitted at activation of immune system ${ }^{1}$
}

\section{Leandro de Melo Pereira ${ }^{2}$, Márcio Gilberto Zangeronimo ${ }^{3}$, Elias Tadeu Fialho ${ }^{2}$, Vinícius de Souza Cantarelli ${ }^{2}$, Hebert Silveira ${ }^{2}$, Cesar Augusto Pospissil Garbossa ${ }^{2}$, Luis Gustavo dos Santos Cerqueira ${ }^{2}$, Thiago Hiroshi Kuribayashi ${ }^{3}$}

\footnotetext{
1 Financiado pelo CNPq com apoio da Fapemig e do INCT - Ciência Animal.

2 Departamento de Zootecnia - Universidade Federal de Lavras, Lavras, MG, Brazil.

${ }^{3}$ Departamento de Medicina Veterinária - UFLA.
}

\begin{abstract}
The objective of this work was to evaluate the performance of piglets in the nursery phase submitted to activation of immune system with vaccine against Haemophilus parasuis and to different levels of metabolizable energy in the diets. It was used 160 barrows and females at 30 days of age, weaned at 23 days of age, with initial weight of $7.97 \pm 0.54 \mathrm{~kg}$, distributed in $2 \times 4$ factorial arrangement (with vaccination and without vaccination with four levels of metabolizable energy - 3,200;3,300; 3,400 and 3,500 kcal/kg). Each combination was evaluated with five repetitions of four animals per experimental plot (two males and two females). Energy levels reduced linearly the intake, feed conversion and the total number of leukocytes in blood in the experimental period, regardless of the use of vaccine which in turn reduced daily average weight gain only in the first week after second application and it increased the number of limonocytes and spleen weight after three weeks. There was no difference in the C-reactive protein quantity in the blood in the periods when it was evaluated. The use of vaccine reduces performance immediatelly after its application but after it occurs recovery of performance with changes in the number of monocytes and spleen weight. Dietary energy levels do not smooth this reduction in the performance, but they influence intake, feed conversion and blood parameters in the total period of use.
\end{abstract}

Key Words: immunologic challenge, nutrition, swine, vaccine

\section{Introduction}

The use of vaccines in swine production systems is a rather common practice, especially in the current confinement systems, in which it is very easy the growth and proliferation of microorganisms which interfere negatively on performance. Moreover, the pressure for the marketing of healthy pigs and good carcass and the current disease control programs that block the export trade reinforces the importance of using of vaccine programs. However, when exposed to immune activation, pigs can be reduced by $10-40 \%$ in the efficiency of muscle gain, representing between $5-20 \%$ of carcass income (Staley, 1993).

The activation of the immune system increases the amino acids catabolism for gluconeogenesis to meet higher energy demands for production of components of the body defense (Shurson \& Johnston, 1998). Moreover, the normal intake of metabolic energy in the first week after weaning is only $60-70 \%$ of the need of the animal (Dividich \& Seve, 2000), showing a deficit at this stage that can be enhanced with the immunological activation caused, for example, by vaccination programs. This may explain, sometimes, a decrease in animal performance in the first weeks after vaccination.

Thus, understanding the effects of immune system activation and its relationship with energy and nutrient needs of the animals is a central issue in the development of feeding strategies and the success of vaccine programs. Therefore, the present study was conducted to study the influence of different metabolizable energy levels in diets for starter pigs submitted to vaccines program in the nursery phase.

\section{Material and Methods}

All methods used in these experiments related to animal care were approved by the committee of animal care and use of the Universidade Federal de Lavras - UFLA.

The experiment was conducted in the Centro Experimental de Suínos at the Universidade Federal de Lavras - MG, Brazil, in the nursery barn equipped with electric heater and suspended pens separated by bars, with dimensions of $1.20 \times 1.14 \mathrm{~m}$, equipped with plastic slatted floor, trough type feeders and water trough pacifier. 
The ambient temperature was maintained at $29.0 \pm 1.0^{\circ} \mathrm{C}$ in the first week, reduced by $2^{\circ} \mathrm{C}$ in the second and third weeks, respectively, and kept that way until the end of the experiment.

A total of 160 barrows and females (Toppigs $40 \times$ Toppi) weaned at 23 days of age, with initial weight of $6.79 \pm 0.45 \mathrm{~kg}$ were used. For performance in the total experimental period, a randomized block design in $2 \times 4$ factorial arrangement (two levels of immune system activation - no vaccinated or vaccinated - and four levels of metabolizable energy -3,200 $3,300,3,400$ and $3,500 \mathrm{kcal} / \mathrm{kg}$ ) was utilized. The combinations were evaluated with five replicates (initial weight), in plots of four (two males and two females). For hematological parameters and organ weights, one animal per treatment was used as an experimental unit. For the performance within each period (0-14 days; $14-20$ days and 20-34 days), the same experimental design was used, in a split plot in time, however.
To avoid the influence of stress response in the first week of vaccination, the animals were kept on a unique diet after the formation of the lots (adjustment period). On the eighth (experimental day 1 ) and $22^{\text {nd }}$ day after weaning, Haemophilus parasuis serotype five vaccine was administered in half of the animals, following the recommendations by the manufacturer. The vaccines had an adjuvant aluminum hydroxide gel. In the other half, the same volume of sterile saline solution (placebo) was injected.

Feeding was ad libitum with diets based on corn and soybean meal, following the recommendations proposed by Rostagno et al. (2005), except for crude protein and metabolizable energy. Diets were formulated to contain reduced levels of crude protein (17\%), maintaining the ideal relationship between the key amino acids through the inclusion of crystalline amino acids (lysine, methionine, threonine and tryptophan), following the ideal protein concept (Table 1).

Table 1 - Chemical composition and percentage of the ingredients used in the experimental diets (as fed basis)

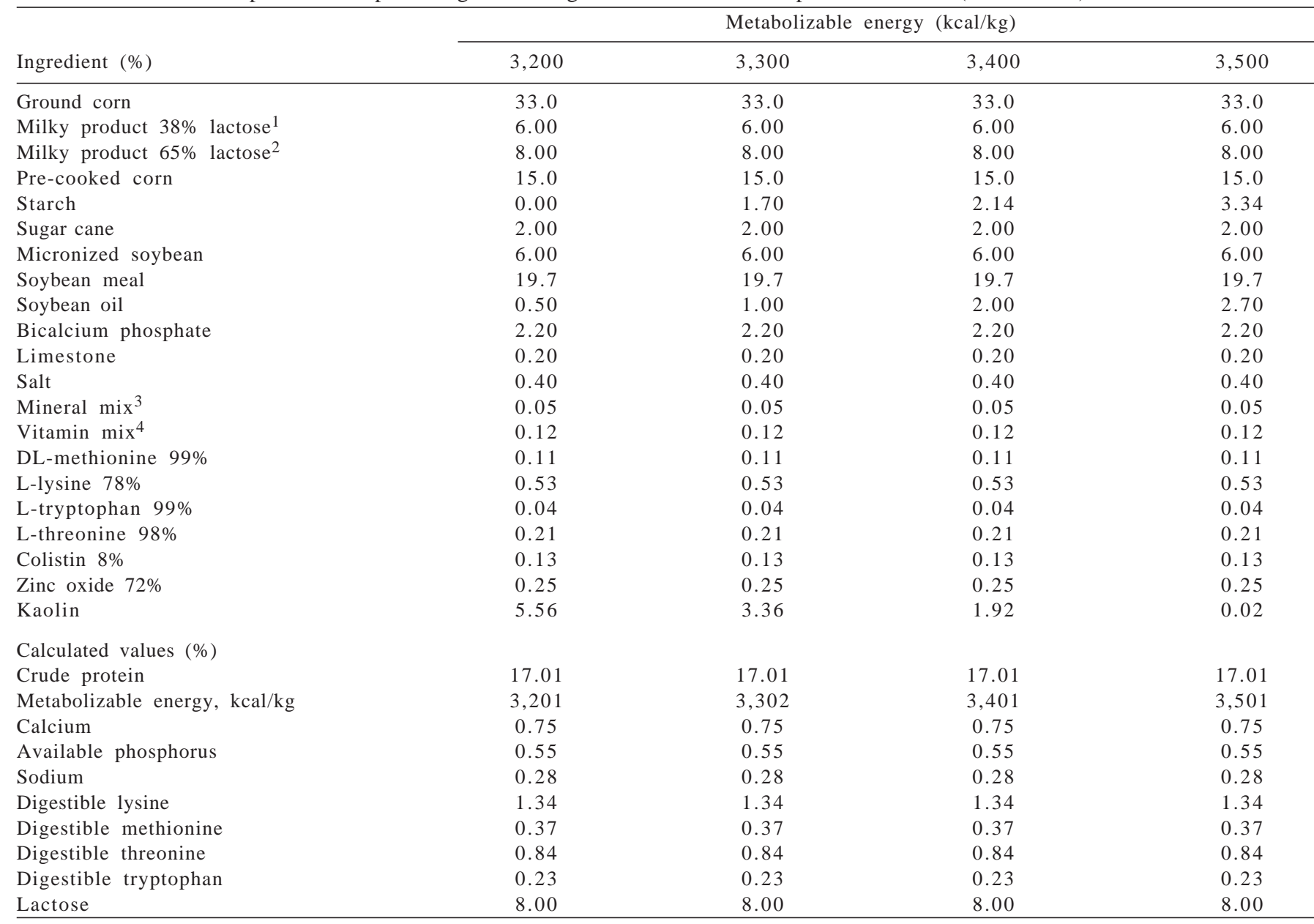

${ }^{1}$ Commercial product: Nuklospray K-51; ${ }^{2}$ Commercial product: Sweelac; ${ }^{3}$ Mineral supplement containing, per kg of product: selenium - $500 \mathrm{mg}$; iron - 70,000 mg; copper 20,000 mg; manganese, 40,000 mg; zinc- 80,000 mg; iodine - $800 \mathrm{mg}$, cobalt - 500mg; ${ }^{4}$ Vitamin supplement containing per kg of product: Vitamin A - 8,000,000 IU, vitamin D3 - 1,200,000 IU; vitamin E - 20,000 mg; vitamin K3 - 2,500 mg; vitamin B1 - 1000 mg; Riboflavin (B2) - 4.000 mg; pyridoxine (B6) - 2000 mg; vitamin B12 - 20,000 mg; niacin - 25,000 mg; pantothenic acid - 10,000 mg; folic acid - 600 mg; Biotin - 50 mg; vitamin C - 50,000 mg; Antioxidant - $125 \mathrm{mg}$. 
On the $20^{\text {th }}$ and $34^{\text {th }}$ days of experiment (one week and 21 days after second doses of vaccination), all animals were weighed after 12-hour fasting and one pig per pen was slaughtered after electrical desensitization followed by bleeding through the jugular vein. Animal was chosen based on the average weigh of the experimental unit. At this time, samples of $10 \mathrm{~mL}$ of blood containing anticoagulant (heparin) were collected and sent to a commercial clinical laboratory for measurement of hematological parameters using the technique of flow cytometry. Other $10-\mathrm{mL}$ sample without anticoagulant was used to obtain serum to quantify C-reactive protein by imunoturbidimetry assay using the kit Bioclin PCR K059. Only on the $34^{\text {th }}$ day, animals were eviscerated. Liver, spleen and thymus were dissected and weighed on a precision scale to obtain the relative weight with regard to body weight at slaughter time.

Average weight gain, average daily feed intake, feed conversion, number of total leukocytes and percentage of monocytes, eosinophils, lymphocytes and relative weights of liver, spleen and thymus were analyzed.

Data were subjected to analysis of variance and the averages were obtained from animals vaccinated or not compared by $\mathrm{F}$ test. Energy levels were submitted to regression analysis. For the blood variables and organs weight, data were transformed $(x+0.5$ root and square root, respectively) to achieve normality, except for percentage of eosinophils, which were submitted to nonparametric statistical analysis. In this case, means were compared by Kruskal-Wallis test. All statistical analyzes were performed in the SAS statistical program (1998).

\section{Results and Discussion}

The results showed no interaction $(\mathrm{P}>0.05)$ between dietary energy levels and vaccinated or non-vaccinated animals considering the weight gain, feed intake and feed conversion during the total period of evaluation (Table 2). For weight gain, no influence of these factors $(\mathrm{P}>0.05)$ was observed, but the increase of dietary energy reduced $(\mathrm{P}<0.05)$ linearly the feed intake and feed conversion of the animals.

These results indicate that the energy density in the diet controls the intake without interfering with the daily weight gain of piglets. However, this only occurs when the diet meets the nutritional requirements of animals (Beaulieu et al., 2006).

Spurlock et al. (1997) compared two energy levels (3,300 or 3,500 kcal of ME/kg) in the diets for pigs from 25 to $55 \mathrm{~kg}$ challenged with Escherichia coli and Lippolysaccharide and found no difference in average weight gain in the total period of experiment (36 days).

It is well-known that intake of animals is directly related to the dietary energy levels, as it can be observed in the present work. The influence of the activated immune system in consumption (Shurson \& Johnston, 1998) could result in lower supply of nutrients to the body. In this case, the adjustment of dietary energy levels might be necessary to maintain the animal development.

By considering the performance of piglets in the first two weeks after the first vaccination (0-14 days of experiment) and the performance in the following week after the second dose (14 to 20 days), it was observed no

Table 2 - Performance of piglets from 30 to 64 days of age, vaccinated or non-vaccinated to Haemophilus parasuis, evaluated in different phases and fed diets with different levels of metabolizable energy

\begin{tabular}{|c|c|c|c|c|c|c|c|c|c|}
\hline & \multicolumn{8}{|c|}{ Metabolizable energy (kcal/kg) } & \multirow[t]{3}{*}{ CV (\%) } \\
\hline & \multicolumn{2}{|c|}{3,200} & \multicolumn{2}{|c|}{3,300} & \multicolumn{2}{|c|}{3,400} & \multicolumn{2}{|c|}{3,500} & \\
\hline & Vaccinated & $\begin{array}{c}\text { Non- } \\
\text { vaccinated }\end{array}$ & Vaccinated & $\begin{array}{c}\text { Non- } \\
\text { vaccinated }\end{array}$ & Vaccinated & $\begin{array}{c}\text { Non- } \\
\text { vaccinated }\end{array}$ & Vaccinated & $\begin{array}{c}\text { Non- } \\
\text { vaccinated }\end{array}$ & \\
\hline \multicolumn{10}{|l|}{14 days after first dose } \\
\hline Weight gain (g/day) & 386 & 394 & 389 & 390 & 366 & 403 & 402 & 361 & 14.25 \\
\hline Feed intake (g/day) ${ }^{1}$ & 667 & 700 & 646 & 632 & 596 & 643 & 623 & 578 & 5.95 \\
\hline Feed conversion & 1.73 & 1.78 & 1.66 & 1.62 & 1.63 & 1.60 & 1.55 & 1.64 & 21.22 \\
\hline \multicolumn{10}{|c|}{7 days after second dose } \\
\hline Weight gain (g/day) ${ }^{2}$ & 597 & 744 & 497 & 722 & 557 & 691 & 533 & 627 & 14.25 \\
\hline Feed intake (g/day) ${ }^{2}$ & 1568 & 1733 & 1559 & 1571 & 1525 & 1575 & 1543 & 1608 & 5.95 \\
\hline Feed conversion ${ }^{2}$ & 2.63 & 2.33 & 3.14 & 2.18 & 2.74 & 2.28 & 2.89 & 2.56 & 21.22 \\
\hline \multicolumn{10}{|c|}{ Total period evaluated (30-64 days of age) } \\
\hline Weight gain (g/day) & 601 & 600 & 573 & 575 & 550 & 592 & 584 & 575 & 6.06 \\
\hline Feed intake (g/day) ${ }^{3}$ & 1106 & 1151 & 1069 & 1050 & 1006 & 1098 & 1055 & 1008 & 5.69 \\
\hline Feed conversion ${ }^{3}$ & 1.84 & 1.92 & 1.87 & 1.83 & 1.83 & 1.85 & 1.81 & 1.75 & 3.93 \\
\hline
\end{tabular}

$\mathrm{CV} \%$ = coefficient of variation.

${ }^{1}$ Linear regression for non-vaccinated animals $(\mathrm{P}<0.05) ;{ }^{2}$ Vaccinated and non-vaccinated differ by $\mathrm{F}$ test $(\mathrm{P}<0.05) ;{ }^{3}$ Linear regression $(\mathrm{P}<0.05)$ considering vaccinated and non-vaccinated animals. 
interaction $(\mathrm{P}>0.05)$ between dietary energy and vaccination programs, except for feed intake after first dose, which decreased linearly $(\mathrm{P}<0.05)$ as dietary energy levels increased only in non-vaccinated animals. This shows that in immune-stimulated animals, the energy levels of the feed cannot be the main intake regulatory factor. However, after the second vaccine dose (14 days of experiment), all animals had a decrease in feed intake $(\mathrm{P}<0.05)$, regardless of activation, but the animals which did not receive the antigen had a higher feed intake $(\mathrm{P}<0.05)$.

There were no differences $(\mathrm{P}>0.05)$ among weight gain, feed intake and feed conversion after the first dose of vaccine, but there was a reduction in weight gain $(\mathrm{P}<0.05)$ and feed intake in the first week after the second challenge, which was reflected in the worst feed conversion $(\mathrm{P}<0.05)$. According to Shurson \& Johnston (1998), the increase of tissue catabolism after activation of the immune system can be related to this process. Moreover, another likely explanation is the reduction of serum IGF-I (insulin-like growth factor type I), according to what was observed by Davis et al. (2010). These authors inoculated orally Salmonella in pigs in the initial phase and observed reduction in the weight gain of the animals. In the same study, the authors found an increase in body temperature of animals in the first week after inoculation, reflecting the lower feed consumption ten days after activation.

According to Johnson (1997), activation of the immune system causes, in addition to metabolic changes, neuroendocrine and behavioral changes, acting on the central control of hungry in central nervous system and reducing the food intake.
The lower consumption resulting from the activation of the immune system in the first week after the second dose of vaccine resulted in less weight gain $(\mathrm{P}<0.05)$, also raising the feed conversion $(\mathrm{P}<0.05)$. This may be caused by the release of cytokines by immune system cells, increasing the protein and amino acid catabolism for gluconeogenesis (Shurson \& Johnston, 1998). Despite the deleterious effect of activation of the immune system through vaccines, the animal performance, considering the overall period evaluated, was similar to unvaccinated animals, but studies must be conducted with animals permanently immunostimulated by natural agents present in contaminant quantities.

There was no interaction ( $\mathrm{P}>0.05)$ between dietary energy and vaccine programs. Neither was there difference $(\mathrm{P}>0.05)$ in the hematological parameters of the animals evaluated one week after the second dose of vaccine (Table 3 ). On day 21 after second dose, there was no interaction ( $\mathrm{P}>0.05$ ) between dietary energy and vaccine programs, but it was observed linear reduction of the number of total leukocytes with increasing dietary energy levels and greater monocytes percentage in the group of animals that received antigens. These results reflect the response of piglets to the activation of the immune system, increasing the number of cells capable of becoming macrophages in tissues to phagocyte the invading agents (vaccinal agent) (Abbas et al., 2008). However, the reduction of the total number of leukocytes in the blood due to increase in dietary energy levels may be a result of lower nutrient input stemmed from the diet, since it was observed reduction in consumption on the total period of experiment. This fact evidences the possibility of maintaining the dietary nutrients and energy ratio when levels of dietary energy are increased.

Table 3 - Hematological parameters of piglets vaccinated or not for Haemophilus parasuis, fed diets with different dietary energy levels

\begin{tabular}{|c|c|c|c|c|c|c|c|c|c|}
\hline & \multicolumn{8}{|c|}{ Metabolizable energy (kcal/kg) } & \multirow[t]{3}{*}{ CV $(\%$} \\
\hline & \multicolumn{2}{|c|}{3,200} & \multicolumn{2}{|c|}{3,300} & \multicolumn{2}{|c|}{3,400} & \multicolumn{2}{|c|}{3,500} & \\
\hline & Vaccinated & $\begin{array}{c}\text { Non- } \\
\text { vaccinated }\end{array}$ & Vaccinated & $\begin{array}{c}\text { Non- } \\
\text { vaccinated }\end{array}$ & Vaccinated & $\begin{array}{c}\text { Non- } \\
\text { vaccinated }\end{array}$ & Vaccinated & $\begin{array}{c}\text { Non- } \\
\text { vaccinated }\end{array}$ & \\
\hline \multicolumn{10}{|l|}{7 days after second dose } \\
\hline Total leukocytes $\left(\times 10^{3}\right.$ cells $\left./ \mathrm{mm}^{3}\right)$ & 12.2 & 13.3 & 13.6 & 15.8 & 16.5 & 17.9 & 14.2 & 13.6 & 12.53 \\
\hline Neutrophils (\%) & 70.3 & 75.3 & 71.7 & 78.8 & 70.5 & 75.0 & 77.9 & 73.8 & 6.96 \\
\hline Eosinophils (\%) & 5.58 & 2.86 & 0.73 & 5.58 & 2.91 & 5.14 & 2.53 & 0.73 & 47.57 \\
\hline Serum C-reactive protein (mg/L) & 2.06 & 2.56 & 2.05 & 1.63 & 1.19 & 2.08 & 1.76 & 1.60 & 24.19 \\
\hline \multicolumn{10}{|l|}{21 days after second dose } \\
\hline Total leukocytes ${ }^{1}\left(\times 10^{3}\right.$ cells $\left./ \mathrm{mm}^{3}\right)$ & 3) 14.0 & 14.9 & 12.0 & 14.9 & 11.9 & 13.5 & 11.7 & 9.56 & 12.41 \\
\hline Neutrophils (\%) & 71.3 & 70.2 & 76.4 & 73.8 & 81.2 & 72.0 & 74.4 & 78.6 & 5.31 \\
\hline
\end{tabular}

$\mathrm{CV} \%=$ coefficient of variation; ${ }^{1}$ Linear regression for non-vaccinated animals $(\mathrm{P}<0.05) ;{ }^{2}$ Vaccinated and non-vaccinated differ by $\mathrm{F}$ test $(\mathrm{P}<0.05)$. 
Importantly, under the conditions of this experiment, animals had contact, primarily through the respiratory and gastrointestinal mucosa, with microorganisms or antigenic particles in the environment, usually found on commercial farms. This type of contact certainly may have influenced the results.

Chiquieri et al. (2007), when evaluating leukocyte count in piglets, observed that animals fed diet without growth promoter had increased blood concentrations of neutrophils and monocytes. In the case of the present experiment, colistin and zinc oxide were used as growth promoting agents, but the amount of feed intake and metabolic and physiological state of the animal may also influence the population of blood cells.

No difference $(\mathrm{P}>0.05)$ was observed among the values of $\mathrm{C}$-reactive protein in plasma of piglets on the seventh and $21^{\text {st }}$ day after exposure to the second vaccine dose (Table 3 ). These results may be related to an early resolution of the inflammatory process triggered by vaccines (Stefano, 2004). According to the author, the amount of C-reactive protein in blood plasma normalizes after the third or fifth day of dealing with this process.

Eckersall et al. (1996), evaluated the responses of $\alpha$-1-acid glycoprotein, ceruloplasmin, haptoglobin and C-reactive protein in pigs after challenge with terebintine, and reported that the latter was elevated in only two days after challenge. These studies show that these substances, considered acute phase proteins, remain at high levels in the bloodstream for short periods and that the detection in its variations must be made at shorter intervals than those used in this study.

There were no interaction $(\mathrm{P}>0.05)$ between dietary energy and vaccine programs for relative weight of liver and thymus of pigs (Table 4). Also, there were no differences $(\mathrm{P}>0.05)$ in relative liver and thymus weight of pigs challenged and not challenged by antigen or fed diets with different dietary energy levels. Only the spleen weight increased $(\mathrm{P}<0.05)$ in animals that were immunologically stimulated by the vaccine.

According to Abbas et al. (2008), the spleen is the primary site of immune responses to blood antigens, corresponding to the second line of defense of the immune system. The first includes the lymph nodes and mucosaassociated lymphoid tissue, which are responsible for antigens from lymph. After exposure to antigens of animals, most of the initial response of antibodies occurs in these lymphoid tissues.

The liver is the main site of degradation of amino acids and nitrogen metabolism (Chen et al., 1995), besides being a major producer of proteins involved in immune activation (Piñeiro et al., 2007). However, the acute immune activation caused by the vaccine was not sufficient to significantly alter the weight of this organ.

However, thymus contains many precursors of developing $\mathrm{T}$ lymphocytes, being responsible for the maturation of these cells. There was, in the present study, an increased numbers of lymphocytes, which explains these results.

Table 4 - Relative weight of liver, spleen and thymus of piglets 21 days after the second dose of vaccine for Haemophilus parasuis fed diets with different dietary energy levels

\begin{tabular}{|c|c|c|c|c|c|c|c|c|c|}
\hline \multirow[t]{3}{*}{ Relative weight (\%) } & \multicolumn{8}{|c|}{ Level of energy in the diet $(\mathrm{kcal} / \mathrm{kg})$} & \multirow[t]{3}{*}{ CV (\%) } \\
\hline & \multicolumn{2}{|c|}{3,200} & \multicolumn{2}{|c|}{3,300} & \multicolumn{2}{|c|}{3,400} & \multicolumn{2}{|c|}{3,500} & \\
\hline & Vaccinated & $\begin{array}{c}\text { Non- } \\
\text { vaccinated }\end{array}$ & Vaccinated & $\begin{array}{c}\text { Non- } \\
\text { vaccinated }\end{array}$ & Vaccinated & $\begin{array}{c}\text { Non- } \\
\text { vaccinated }\end{array}$ & Vaccinated & $\begin{array}{c}\text { Non- } \\
\text { vaccinated }\end{array}$ & \\
\hline Liver & 2.38 & 2.19 & 2.35 & 2.19 & 2.30 & 2.31 & 2.30 & 2.57 & 11.51 \\
\hline Spleen $^{1}$ & 0.18 & 0.18 & 0.22 & 0.15 & 0.22 & 0.17 & 0.19 & 0.16 & 10.58 \\
\hline Thymus & 0.43 & 0.41 & 0.38 & 0.41 & 0.40 & 0.41 & 0.43 & 0.38 & 9.43 \\
\hline
\end{tabular}

$\mathrm{CV} \%$ = coefficient of variation; ${ }^{1}$ Vaccinated and non-vaccinated differ by $\mathrm{F}$ test $(\mathrm{P}<0.05)$.

\section{Conclusions}

The activation of the immune system through vaccines reduces the performance of post-weaning pigs only during the first week after the second application (14 days after the first application), but the animals can show compensatory growth in subsequent periods, presenting similar performance to the non-vaccinated ones. The variation of the dietary energy levels does not mitigate this low initial performance, it only influences intake, feed conversion and blood parameters in all piglets. 


\section{Acknowledgements}

The authors gratefully acknowledge FAPEMIG (Research Support Foundation of Minas Gerais) and CNPq (National Council for Research and Development) for their financial support.

\section{References}

ABBAS, A.K.; LICHTMAN, A.H.; PILLAI, S. Imunologia celular e molecular. 6.ed. Philadelphia, PA.: W. B. Saunders Co., 2008. 538p.

BEAULIEU, A.D.; LEVESQUE, C.L.; PATIENCE, J.F. The effects of dietary energy concentration and site of weaning on weanling pig performance. Journal of Animal Science, v.84, p.1159-1168, 2006.

CHEN, H.Y.; MILLER, P.S.; LEWIS, A.J. et al. Changes in plasma urea concentration can be used to determine protein requirements of two populations of pigs with different protein accretion ration. Journal of Animal Science, v.73, n.9, p.261-2639, 1995.

CHIQUIERI, J.; SOARES, R.T.R.N.; NERY, V.L.H. et al. Bioquímica sangüínea e altura das vilosidades intestinais de suínos alimentados com adição de probiótico, prebiótico e antibiótico. Revista Brasileira de Saúde e Produção Animal, v.8, n.2, p.97-104, 2007.

DAVIS, B.L.; FRASER, J.N.; BURKEY, T.E. et al. Oral inoculation with Salmonella enterica serovars Typhimurium or Choleraesuis promotes divergent responses in the somatotropic growth axis of swine. Journal of Animal Science, v.88, n.5, p.1642-1648, 2010.

ECKERSALL, P.D.; SAINI, P.K.; MCCOMB, C. The acute phase response of acid soluble glycoprotein, a1-acid glycoprotein, ceruloplasmin, haptoglobin and C-reactive protein, in the pig. Veterinary Immunology Immunopathology, v.51, p.377-385, 1996.

JOHNSON, R.W. Inhibition of growth by pro-inflammatory cytokines: an integrated view. Journal of Animal Science, v.75, p.1244-1255, 1997.

LE DIVIDICH, J.; SÈVE, B. Effects of underfeeding during the weaning period on growth, metabolism, and hormonal adjustments in the piglet. Domestic Animal Endocrinology, v.19, p.63-74, 2000.

PIÑEIRO, M.; PIÑEIRO, C.; CARPINTERO, R. et al. Characterisation of the pig acute phase protein response to road transport. Veterinary Journal, v.173, p.669-674, 2007.

ROSTAGNO, H.S.; ALBINO, L.F.T.; DONZELE, J.L. et al. Tabelas brasileiras para aves e suínos: composição de alimentos e exigências nutricionais. 2.ed. Viçosa, MG: UFV, Departamento de Zootecnia, 2005. 186p.

SHURSON, J.; JOHNSON, L. Swine nutrition and healt connections. In: ALLEN LEMAN SWINE CONFERENCE, 25., 1998, Saint Paul. Proceedings... Saint Paul: University of Minnessota, 1998. p.77-95.

SPURLOCK, M.E.; FRANK, G.R.; WILLIS, G.M. et al. Effect of dietary energy source and immunological challenge on growth performance and immunological variables in growing pigs. Journal of Animal Science, v.75, n.3, p.720-726, 1997.

STAHLEY, T. Nutrition effects lean growth, carcass composition. Feedstuffs, v.65, n.26, p.12, 1993.

STATISTICAL ANALYSIS SYSTEM - SAS. User's guide, version 6.12, 4.ed, v.2, Cary: 1998. 842p.

STEFANO, A.C. Impacto da dosagem seriada da proteína $C$ reativa na suspensão da antibioticoterapia no período neonatal. 2004. 110f. Dissertação (Mestrado - Universidade Federal de São Paulo) - Escola Paulista de Medicina, São Paulo. 